\title{
TU/e EmonOWEN

\section{Mass transfer to and copper deposition on a round bar in a new type of electrolytic cell: the helix cell}

\section{Citation for published version (APA):}

Janssen, L. J. J., \& Wijers, J. G. (1989). Mass transfer to and copper deposition on a round bar in a new type of electrolytic cell: the helix cell. Journal of Applied Electrochemistry, 19(6), 823-828.

https://doi.org/10.1007/BF01007929

DOI:

10.1007/BF01007929

Document status and date:

Published: 01/01/1989

\section{Document Version:}

Publisher's PDF, also known as Version of Record (includes final page, issue and volume numbers)

\section{Please check the document version of this publication:}

- A submitted manuscript is the version of the article upon submission and before peer-review. There can be important differences between the submitted version and the official published version of record. People interested in the research are advised to contact the author for the final version of the publication, or visit the $\mathrm{DOI}$ to the publisher's website.

- The final author version and the galley proof are versions of the publication after peer review.

- The final published version features the final layout of the paper including the volume, issue and page numbers.

Link to publication

\section{General rights}

Copyright and moral rights for the publications made accessible in the public portal are retained by the authors and/or other copyright owners and it is a condition of accessing publications that users recognise and abide by the legal requirements associated with these rights.

- Users may download and print one copy of any publication from the public portal for the purpose of private study or research.

- You may not further distribute the material or use it for any profit-making activity or commercial gain

- You may freely distribute the URL identifying the publication in the public portal.

If the publication is distributed under the terms of Article 25fa of the Dutch Copyright Act, indicated by the "Taverne" license above, please follow below link for the End User Agreement:

www.tue.nl/taverne

Take down policy

If you believe that this document breaches copyright please contact us at:

openaccess@tue.nl

providing details and we will investigate your claim. 


\title{
Mass transfer to and copper deposition on a round bar in a new type of electrolytic cell: the helix cell
}

\author{
L. J. J. JANSSEN, J. G. WIJERS \\ Faculty of Chemical Technology, Eindhoven University of Technology, PO Box 513,5600 MB Eindhoven, \\ The Netherlands
}

Received 22 September 1988; revised 23 January 1989

High-rate electrodeposition of copper from $\mathrm{CuSO}_{4}-\mathrm{H}_{2} \mathrm{SO}_{4}$ baths can be achieved by using crossflow of solution. To obtain copper layers of uniform thickness and quality, a new type of electrolytic cell, the helix cell, has been proposed. An experimental dimensionless relation has been given to describe the mass transfer to a round bar, in crossflow, in a helix cell. Moreover, the current efficiency of copper deposition has been obtained as a function of current density, flow rate of solution, temperature and weight per cent $\mathrm{CuSO}_{4}$ in the $\mathrm{CuSO}_{4}-\mathrm{H}_{2} \mathrm{SO}_{4}$ solution.

\section{Nomenclature}

\begin{tabular}{|c|c|}
\hline$A_{\mathrm{e}}$ & working-electrode surface area $\left(\mathrm{m}^{2}\right)$ \\
\hline & concentration of $\mathrm{Cu}^{2+}\left(\mathrm{mol} \mathrm{m}^{-3}\right)$ \\
\hline$c_{\mathrm{e}}$ & $c$ at electrode surface $\left(\mathrm{mol} \mathrm{m}^{-3}\right)$ \\
\hline$c_{\mathrm{b}}$ & $c$ in bulk of solution $\left(\mathrm{mol} \mathrm{m}^{-3}\right)$ \\
\hline $\mathrm{C}$ & constant factor $(-)$ \\
\hline$d_{\mathrm{c}}$ & $\begin{array}{l}\text { inner diameter of central cylinder of } \\
\text { helix cell }(\mathrm{mm})\end{array}$ \\
\hline$d_{\mathrm{h}}$ & $\begin{array}{l}\text { volumetric hydraulic diameter of helix } \\
\text { cell }(\mathrm{mm})\end{array}$ \\
\hline$d_{\mathrm{s}}$ & $\begin{array}{l}\text { width of helical slots in central cylinder } \\
\text { of helix cell }(\mathrm{mm})\end{array}$ \\
\hline$d_{\mathrm{w}}$ & $\begin{array}{l}\text { diameter of working electrode (round } \\
\text { bar) }(\mathrm{mm})\end{array}$ \\
\hline$D_{i}$ & diffusion coefficient of species $i\left(\mathrm{~m}^{2} \mathrm{~s}^{-1}\right)$ \\
\hline$r$ & Faraday constant $\left(\mathrm{C} \mathrm{mol}^{-1}\right)$ \\
\hline$I$ & current (A) \\
\hline$k_{i}$ & $\begin{array}{l}\text { mass-transfer coefficient for a species i } \\
\left(\mathrm{m} \mathrm{s}^{-1}\right)\end{array}$ \\
\hline$i$ & current density $\left(\mathrm{kA} \mathrm{m}^{-2}, \mathrm{~A} \mathrm{~m}^{-2}\right)$ \\
\hline$L_{\mathrm{c}}$ & $\begin{array}{l}\text { length of working-electrode compart- } \\
\text { ment of helix cell (m) }\end{array}$ \\
\hline
\end{tabular}

\begin{tabular}{|c|c|}
\hline$n$ & $\begin{array}{l}\text { number of electrons involved in elec- } \\
\text { trode reaction (-) }\end{array}$ \\
\hline $\mathrm{n}_{1}, \mathrm{n}_{2}, \mathrm{n}_{3}$ & constants $(-)$ \\
\hline $\mathrm{R}$ & gas constant: $\mathrm{R}=8.31 \mathrm{~J} \mathrm{~K}^{-1} \mathrm{~mol}^{-1}$ \\
\hline $\operatorname{Re}$ & Reynolds number: $\operatorname{Re}=v_{\mathrm{c}} d_{\mathrm{h}} / v(-)$ \\
\hline $\mathrm{Sc}$ & Schmidt number: $\mathrm{Sc}=v / D(-)$ \\
\hline Sh & Sherwood number: $\mathrm{Sh}=k d_{h} / D$ \\
\hline$t$ & time $(s)$ \\
\hline$T$ & temperature $(\mathrm{K})$ \\
\hline$U_{\mathrm{s}}$ & $\begin{array}{l}\text { volumetric rate of solution through the } \\
\text { helix cell }\left(\mathrm{m}^{3} \mathrm{~s}^{-1}\right)\end{array}$ \\
\hline$v_{\mathrm{c}}$ & $\begin{array}{l}\text { flow rate of solution through working- } \\
\text { electrode compartment of the helix cell } \\
\left(v \mathrm{c}=U /\left(d_{\mathrm{c}}-d w\right) L c\right)(m s-1)\end{array}$ \\
\hline$\varrho$ & density of solution $\left(\mathrm{kg} \mathrm{m}^{-3}\right)$ \\
\hline$\mu$ & dynamicviscosityofsolution $(\mathrm{kg} \mathrm{m-1} \mathrm{s-1)}$ \\
\hline$v$ & kinematic viscosity of solution $(m 2 s-1)$ \\
\hline$\eta_{i}$ & $\begin{array}{l}\text { current efficiency for formation of a } \\
\text { species } i\end{array}$ \\
\hline
\end{tabular}

Moreover, the current efficiency for copper deposition from a $\mathrm{CuSO}_{4}-\mathrm{H}_{2} \mathrm{SO}_{4}$ bath has been determined for a wide range of parameters.

\section{Experimental details}

The cross-section of a helix cell is shown schematically in Fig. 1. The separate parts of the cell are presented in Fig. 2. The cell consists of two concentric cylinders, viz. the central cylinder with two helical slots and the outer cylinder. The cylindrically working electrode is placed in the middle of the central cylinder. The inner length of both cylinders, $L_{\mathrm{c}}$, is $60 \mathrm{~mm}$. The inner diameter of the central cylinder, $d_{c}$, varies from $11-19 \mathrm{~mm}$ and the outer diameter for all the central 


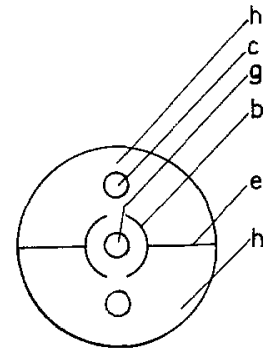

Fig. 1. Cross-section of the helix cell; b, central tube; c, counterelectrode; e, separation wall; g, working electrode; $h$, outer compartment.

cylinders is $24 \mathrm{~mm}$. The helical slots, opposite each other, have a width, $d_{s}$, of between $2.4-6.0 \mathrm{~mm}$ and a pitch of $50 \mathrm{~mm}$. The space between the central and the outer cylinder is divided into two equal counterelectrode compartments by a spiralled Perspex wall. The solution enters one counter-electrode compartment, flows subsequently through one helical slot, the working-electrode compartment and through the other helical slot into the other counter-electrode compartment. The working electrode is a platinum tube $9 \mathrm{~mm}$ in outer diameter, $60 \mathrm{~mm}$ in length and $17 \times$ $10^{-4} \mathrm{~m}^{2}$ in electrode surface area. The platinum tube was polished with diamond paste before its positioning in the cell. The wall thickness of the platinum tube is $0.25 \mathrm{~mm}$. There is a current connection at each end of the platinum tube. It was shown that the ohmic potential drop across the platinum tube is negligible even at the highest current (25 A) applied. Two spiralled copper rods, $5 \mathrm{~mm}$ in diameter, served as the counter-electrode; one rod was placed in each counterelectrode compartment. The temperature of the solution was measured in the overflow vessel and maintained at a constant value to within $1^{\circ} \mathrm{C}$. A common

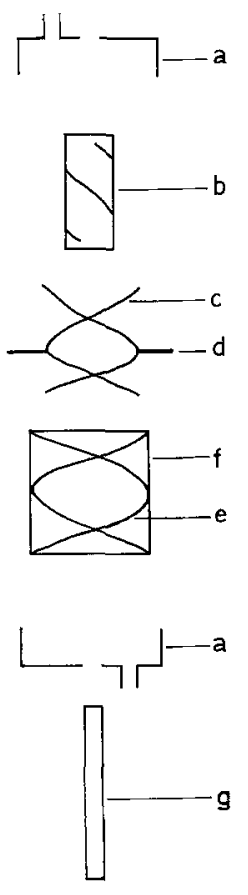

Fig. 2. Separate parts of the helix cell; $a$, cap with liquid inlet; $b$, Perspex cylinder with slots; $\mathrm{c}, \mathrm{Cu}$ bars; $\mathrm{d}$, current connection bars; $\mathrm{e}$, spiral separation wall; $\mathrm{f}$, outer wall of cell; $\mathrm{g}$, working electrode. circuit of solution for forced convection conditions was used. A solution of about $0.01 \mathrm{~m}^{3}$ was pumped through a circuit consisting of electrolytic cell, overflow vessel, heat exchanger, pump and flowmeters.

The flow rate of solution in the working-electrode compartment at the cross-section, $v_{c}$, is equal to the volumetric rate of solution, $U_{\mathrm{s}}$, through the cell, divided by the difference between the cross-section of the working-electrode compartment and that of the working electrode, both in the direction of the axis of the working electrode.

To visualize the pattern of the solution flow, the cell and the solution circuit were filled with water and a small quantity of blue ink was injected. It was observed that the whole length of both slots was practically uniformly used for solution flow.

It is noted that the helix cell can only be used to obtain equal thicknesses of copper deposition around a bar when the bar is transported through the helix cell.

To determine the mass-transfer characteristics, $1 \mathrm{M}$ $\mathrm{H}_{2} \mathrm{SO}_{4}$ or sulphuric $4 \mathrm{M} \mathrm{H}_{2} \mathrm{SO}_{4}$, each containing $2.5 \mathrm{mM} \mathrm{CuSO}_{4}$, were used. The solution was made oxygen-free by nitrogen gas bubbling. The currentefficiency measurements were carried out with $\mathrm{CuSO}_{4}$ / $\mathrm{H}_{2} \mathrm{SO}_{4}$ solutions with various contents of both species. The chosen contents are based on solubility data for the tertiary system $\mathrm{CuSO}_{4}-\mathrm{H}_{2} \mathrm{SO}_{4}-\mathrm{H}_{2} \mathrm{O}$ [2].

Mass-transfer and current-efficiency measurements were carried out in a similar fashion to that described previously [1]. The voltammograms were measured potentiodynamically at a scan rate of $50 \mathrm{mV} \mathrm{s}^{-1}$. The scan started at a potential of $500 \mathrm{mV}$ against saturated calomel electrode which was used as the reference electrode; before taking up a voltammogram, the working platinum electrode was made copper-free by anodic polarization at $500 \mathrm{mV}$ against saturated calomel electrode.

\section{Results and discussion}

\subsection{Mass transfer}

Figure 3 shows two typical voltammograms for the cylindrical platinum electrode in oxygen-free $1 \mathrm{M}$ $\mathrm{H}_{2} \mathrm{SO}_{4}$ solutions; one without $\mathrm{CuSO}_{4}$ and the other containing $2.5 \mathrm{mM} \mathrm{CuSO}_{4}$. The curve for the $\mathrm{CuSO}_{4}-$ $\mathrm{H}_{2} \mathrm{SO}_{4}$ solutions shows a pre-wave at potentials between 0.15 and $0.0 \mathrm{~V}$; its limiting current is almost independent of the solution-flow rate. Moreover, this wave cannot be caused by reduction of dissolved oxygen. In mass-transfer studies, the potential-current curves for copper deposition are not given [3] or given only in the potential range where the limiting diffusion current occurs [4] or for relatively high $\mathrm{CuSO}_{4}$ concentrations where the effect of the pre-wave is negligible. The pre-wave is caused by underpotential deposition of copper on the bare platinum surface [5]. Since the limiting current region of the current-potential curve $\mathrm{Cu}^{2+}$ reduction to $\mathrm{Cu}$ show no well-shaped plateau, determination of the limiting current poses 


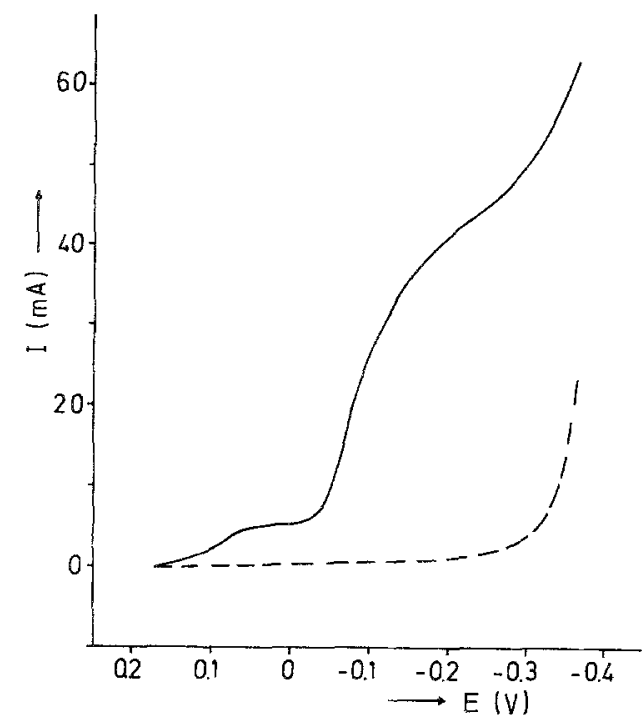

Fig. 3. Voltammograms for the cylindrical platinum electrode in oxygen-free $1 \mathrm{M} \mathrm{H}_{2} \mathrm{SO}_{4}$ solutions with (solid line) and without (dotted line) addition of $2.5 \mathrm{mM} \mathrm{CuSO}_{4}$. Inner diameter of central cylinder: $15 \mathrm{~mm}$. Width of slot in central cylinder: $2.4 \mathrm{~mm}$. Temperature: $298 \mathrm{~K}$, volumetric flow rate of solution: $0.13 \times$ $10^{-3} \mathrm{~m}^{3} \mathrm{~s}^{-1}$.

some problems. The current at the inflection point of the potential-current curves may be accepted as the limiting current, in accord with general practice. The occurrence of the pre-wave has not been taken into account in the determination of the limiting diffusion current of $\mathrm{Cu}^{2+}$ ions because of the explanation of its occurrence. Moreover, unrealistic results are obtained when the pre-wave is taken into account.

The thickness of the $\mathrm{Cu}$ layer present on the smooth Pt tube after the measuring of the voltammogram was very low, namely lower than about $4 \times 10^{-3} \mu \mathrm{m}$. Consequently, the nature of the copper deposit had no effect upon the mass-transfer data.

The reported values for the diffusion coefficient of $\mathrm{Cu}^{2+}$ are scattered over a surprisingly wide range. In particular, rotating disc determinations show the most scatter [4].

The recently published data on the diffusion coefficient of $\mathrm{CuSO}_{4}$ in aqueous solutions at $T=298 \mathrm{~K}$ are discussed and new reliable results are given [4]. From [4] it follows that $D_{\mathrm{Cu}^{2+}}=\left\{7.35-5.3 c_{\mathrm{b}}^{0.5}\right\} \times$ $10^{-10} \mathrm{~m}^{2} \mathrm{~s}^{-1}$ in a $\mathrm{CuSO}_{4}$ solution containing $0.1 \mathrm{M}$ $\mathrm{H}_{2} \mathrm{SO}_{4}$ at $298 \mathrm{~K}$. From this relation for $D_{\mathrm{Cu}^{2}+}$ and since the effect of the viscosity of sulphuric acid solutions is in agreement with the Stokes-Einstein equation [3], it has been calculated that $D_{\mathrm{Cu}^{2}+}$ for a $2.5 \mathrm{mM}$ $\mathrm{CuSO}_{4}+1.0 \mathrm{M} \mathrm{H}_{2} \mathrm{SO}_{4}$ solution at $298 \mathrm{~K}$ is $6.1 \times 10^{-10} \mathrm{~m}^{2} \mathrm{~s}^{-1}$ and for a $2.5 \mathrm{mMCuSO}_{4}+4.0 \mathrm{M}$ $\mathrm{H}_{2} \mathrm{SO}_{4}$ solution at $298 \mathrm{~K}$ is $3.8 \times 10^{-10} \mathrm{~m}^{2} \mathrm{~s}^{-1}$.

Since no reliable results are available on the diffusion coefficient of $\mathrm{Cu}^{2+}$ ions in sulphuric acid solutions over a wide range of temperature, it is assumed that the temperature dependence of $D_{\mathrm{Cu}^{2}+}$ in sulphuric acid solutions is equal to that found for $0.0625 \mathrm{M}$ $\mathrm{CuSO}_{4}[5]$. From results of [5] it was shown that, in the temperature range from $300-330 \mathrm{~K}$, the activation energy for diffusion of $\mathrm{Cu}^{2+}$ ions is $22.21 \mathrm{~kJ} \mathrm{~mol}^{-1}$.
Table 1. Diffusion coefficient for $\mathrm{Cu}^{2+}$ in $1.0 \mathrm{M}$ and $4.0 \mathrm{M} \mathrm{H}_{2} \mathrm{SO}_{4}$ solution, containing $2.5 \mathrm{mM} \mathrm{CuSO}_{4}$ at various temperatures

\begin{tabular}{|c|c|c|}
\hline \multirow[b]{2}{*}{$\begin{array}{l}\text { Temperature } \\
(\mathrm{T} / K)\end{array}$} & \multicolumn{2}{|c|}{$\mathrm{D}_{C u}(I I) \times I 0^{10} m^{2} s^{-1}$} \\
\hline & $1 \mathrm{M} \mathrm{H}_{2} \mathrm{SO}_{4}$ & $4 \mathrm{M} \mathrm{H}_{2} \mathrm{SO}_{4}$ \\
\hline 298 & 6.1 & 3.8 \\
\hline 308 & 8.2 & 5.1 \\
\hline 323 & 12.2 & 7.6 \\
\hline 343 & 19.8 & 12.3 \\
\hline
\end{tabular}

The calculated diffusion coefficient of $D_{\mathrm{Cu}^{(2)}}$ for two solutions at various temperatures is given in Table 1.

To describe mass-transfer characteristics in electrolytic cells, the Sherwood number, Sh, the Reynolds number, Re, and the Schmidt number, Sc, are used frequently. The Sherwood number, $\mathrm{Sh}$, is $k d_{\mathrm{h}} / D$ where $k$ is the mass-transfer coefficient on a circumferenceaverage basis for the working electrode.

The determination of the mass-transfer coefficient is described in [1]. The kinematic viscosity of $1 \mathrm{M} \mathrm{H}_{2} \mathrm{SO}_{4}$ and $4 \mathrm{M} \mathrm{H}_{2} \mathrm{SO}_{4}$ at various temperatures is obtained from $[7,8]$ and tabulated in Table 1 .

The volumetric hydraulic diameter is defined by $d_{\mathrm{h}}=4 \times$ volume of free space for the flow divided by the area of the wetted surface. It can be shown that for the helix cell $d_{\mathrm{h}}=d_{\mathrm{c}}-d_{\mathrm{w}}$.

The Reynolds number is defined by $\operatorname{Re}=v_{\mathrm{c}} d_{\mathrm{in}} / v$. The solution-flow rate $v_{c}$ in the working-electrode compartment is given by $v_{\mathrm{c}}=U_{\mathrm{s}} /\left(d_{\mathrm{c}}-d_{\mathrm{w}}\right) L_{\mathrm{c}}$ and the Reynolds number by $\operatorname{Re}=U_{\mathrm{s}} / v L_{\mathrm{c}}$.

Figure 4 shows $\mathrm{Sh}$ as a function of Re on a double logarithmic plot for a $2.5 \mathrm{mM} \mathrm{CuSO}+1 \mathrm{M} \mathrm{H}_{2} \mathrm{SO}_{4}$ solution at various temperatures. From this figure it follows that the $\log \mathrm{Sh} / \log \mathrm{Re}$ curves are parallel to one another, the slope $n_{1}$ of a $\log S h / l o g$ Re curve increases with increasing $R e$ and $n_{i}$ only depends on Re.

Figure 5 shows $\mathrm{Sh}$ as a function of $\mathrm{Sc}$ on a double logarithmic scale for a $1 \mathrm{M}$ and $4 \mathrm{M} \mathrm{H}_{2} \mathrm{SO}_{4}$ solution, containing $2.5 \mathrm{mM} \mathrm{CuSO}_{4}$. The change in the Schmidt

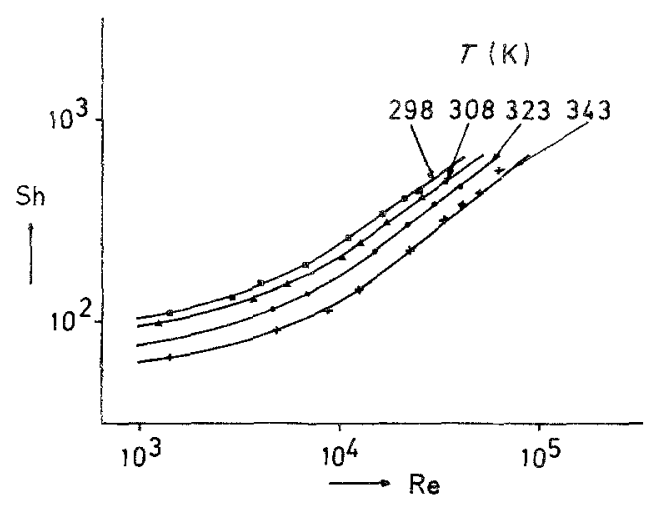

Fig. 4. Sherwood number as a function of Reynolds number for a working cylindrical platinum electrode in $1.0 \mathrm{M} \mathrm{H}_{2} \mathrm{SO}_{4}$ containing $2.5 \mathrm{mM} \mathrm{CuSO}_{4}$ and at various temperatures. The diameter of the working electrode is $9.0 \mathrm{~mm}$, the inner diameter of the central cylinder is $15 \mathrm{~mm}$ and the width of the helical slot in the central cylinder is $4.3 \mathrm{~mm}$. 


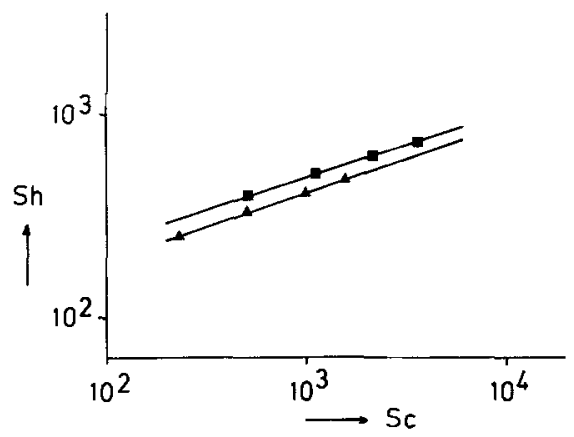

Fig. 5. Sherwood number as a function of Schmidt number for a working cylindrical platinum electrode in 1.0 and $4.0 \mathrm{M} \mathrm{H}_{2} \mathrm{SO}_{4}$, each containing $2.5 \mathrm{mM} \mathrm{CuSO}{ }_{4}$. Diameter of working electrode $9.0 \mathrm{~mm}$; inner diameter of central cylinder $15 \mathrm{~mm}$; width of helical slot in central cylinder $4.3 \mathrm{~mm}$. $4 \mathrm{M} \mathrm{H}_{2} \mathrm{SO}_{4} ; \wedge$ I $\mathrm{M} \mathrm{H}_{2} \mathrm{SO}_{4}$

number was obtained by changing the solution temperature. The two straight lines are parallel, their slope, $\mathrm{n}_{2}$, being 0.33 . This value of slope is quite common for forced convection mass transfer [9] and for wire electrodes in electroplating cells of various designs [10].

It is likely that the observed difference in the positions of the lines is caused by inaccuracies in diffusion coefficient, kinematic viscosity, solution-flow rate and/or limiting current of $\mathrm{Cu}$ deposition.

The effect of the diameter of the helical slot, $d_{s}$, and the inner diameter of the central tube, $d_{c}$, on the Sherwood number at a constant volumetric flow rate of solution, viz. respectively 100 to $150 \mathrm{~cm}^{3} \mathrm{~s}^{-1}$, and at various temperatures, is shown in Figs 6 and 7. From these figures it follows that the Sherwood number does not depend on $d_{\mathrm{s}}$ at $d_{\mathrm{s}}>3.5 \mathrm{~mm}$ and on $d_{\mathrm{c}}$ at $d_{\mathrm{c}}>$ $14 \mathrm{~mm}$. Plotting Sh versus $\mathrm{Re}$ on a double logarithmic scale, it has been found that the slope, $\mathrm{n}_{1}$, is practically independent of $d_{s}$ as well as $d_{c}$.

Summarizing the experimental data on mass transfer to a working cylindrical electrode in a helix cell, it follows that

$$
\mathrm{Sh}=\mathrm{CR \textrm {R } ^ { \mathrm { n } _ { 1 } }} \mathrm{Sc}^{1 / 3}
$$

where the constants $\mathrm{C}$ and $\mathrm{n}_{1}$ depend only on $\operatorname{Re}$ for a helix cell with $d_{\mathrm{s}}>3.5 \mathrm{~mm}$ and $d_{\mathrm{c}}>14 \mathrm{~mm}$. A similar relation has been found for the average heattransfer coefficient for a heated cylinder in crossflow with a constant solution-flow rate outside the boundary.

From Fig. 4 it can be calculated that

$$
\mathrm{Sh}=0.017 \mathrm{Re}^{0.76} \mathrm{Sc}^{1 / 3}
$$

and

$$
\mathrm{Sh}=0.011 \mathrm{Re}^{0.81} \mathrm{Sc}^{1 / 3}
$$

at, respectively, $\operatorname{Re}=2 \times 10^{4}$ and $5 \times 10^{4}$.

Since the slope $\mathrm{n}_{1}$ increases with increasing $\mathrm{Re}, \mathrm{a}$ more practical relation is desirable. The experimental results of Fig. 4 are presented in Fig. 8 by plotting $\mathrm{Sh}_{-} \mathrm{Sh}_{0}$ against $\mathrm{Re}$ on a double logarithmic scale where $\mathrm{Sh}_{0}$ is the extrapolated $\mathrm{Sh}$ at $\mathrm{Re}=0$. From Fig. 8 it follows that the curves are linear and parallel. From this figure and $\mathrm{Sh}_{0}$ derived from Fig. 4 , it follows that, for the $\operatorname{Re}$ range between $3 \times 10^{3}$ and $7 \times 10^{4}$

$$
\mathrm{Sh}=\left(10.0+5.72 \times 10^{-4} \mathrm{Re}^{1.08}\right) \mathrm{Sc}^{0.33} .
$$

The relation for $\mathrm{Sh}$ is useful for helix cells with $d_{\mathrm{s}}>3.5 \mathrm{~mm}$ and $d_{\mathrm{c}}>14 \mathrm{~mm}$ and $d_{\mathrm{w}}=9 \mathrm{~mm}$.

The effect of the diameter of the cylindrical working electrode has not been investigated since electrodes with various diameters were not available.

Grassmann et al. have studied mass transfer to a cylinder electrode in cross flow [10]. They found that $\mathrm{Sh}$ is proportional to $\mathrm{Re}^{\mathrm{n}_{3}}$ for cylindrical working electrodes of 5 and $10 \mathrm{~mm}$ diameter in cross flow. The diameter of the electrode was used as the characteristic length to calculate the Reynolds number. They used a tube of $50 \mathrm{~mm}$ as the electrolytic cell. The working electrode was mounted perpendicularly to the axis of this $50 \mathrm{~mm}$ tube. They found that the coefficient $n_{3}$ increased markedly with increasing $\mathrm{Re} ; \mathrm{n}_{3}=0.44$ for $160<\operatorname{Re}<1000$ and 0.56 for $1000<\operatorname{Re}<12600$. For the helix cell a similar relationship between $\mathrm{Re}$ and Sh has been obtained (Fig. 4). Tvarusko [11] has investigated mass transfer to a wire $(0.25 \mathrm{~mm}$ in diameter) in cross flow. Tvarusko's electrolytic cell was similar to that used by Grassmann et al. He found that

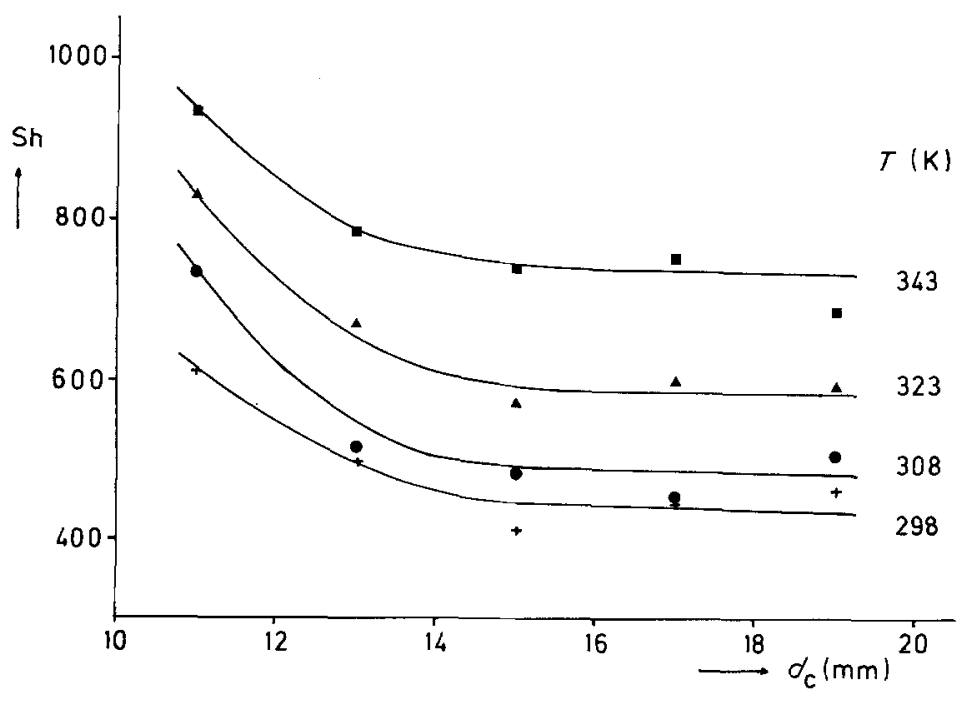

Fig. 6. Sherwood number as a function of the inner diameter of the central Perspex cylinder of the helix cell for a working cylindrical platinum electrode (diameter $9.0 \mathrm{~mm}$ ) in a $2.5 \mathrm{mM} \mathrm{CuSO}_{4}+1 \mathrm{M} \mathrm{H}_{2} \mathrm{SO}_{4}$ solution at various temperatures. Width of helical slot $4.3 \mathrm{~mm}$; volumetric flow rate $0.15 \times 10^{-3} \mathrm{~m}^{3} \mathrm{~s}^{-1}$. 


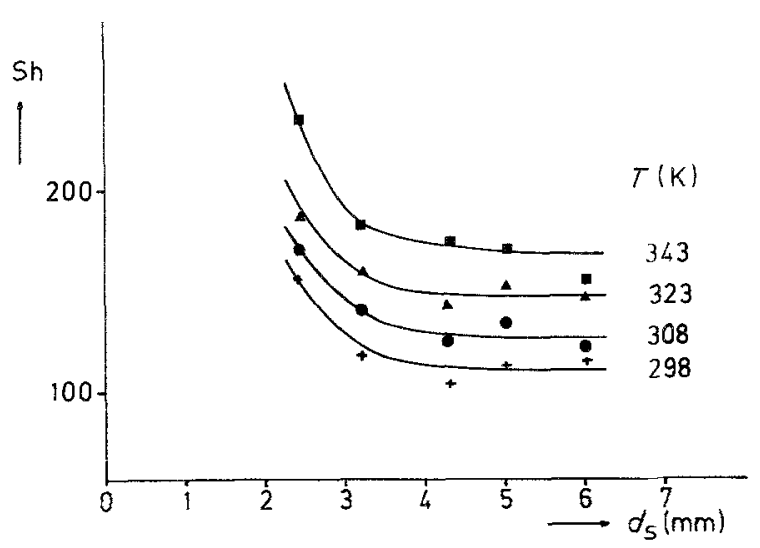

Fig. 7. Sherwood number as a function of the width of the helical slot in the central Perspex cylinder of the helix cell for a working cylindrical platinum electrode (diameter $9.0 \mathrm{~mm}$ ) in a $2.5 \mathrm{mM}$ $\mathrm{CuSO}_{4}+1 \mathrm{M} \mathrm{H}_{2} \mathrm{SO}_{4}$ solution at various temperatures. Inner diameter of central Perspex cylinder $15 \mathrm{~mm}$; volumetric flow rate $0.10 \times 10^{-3} \mathrm{~m}^{3} \mathrm{~s}^{-1}$.

Sh is proportional to $\mathrm{Re}^{0.49} \mathrm{Sc}^{0.33}$ for Reynolds numbers between $100-200$. It should be noted that the design of the helix cell is completely different from that used by Grassmann et al.

The data on mass transfer to the cylinder working electrode in a helix cell are practically unaffected by entrance length effects, when the difference in pressure over each of the two counter-electrode compartments is much lower than that between both the counterelectrode compartments. The dimensions of some parts of the helix cell, for instance the width of the helical slots and the diameter of the central tube, the working electrode and of the outer cylinder, strongly affect the differences in pressure inside the helix cell.

From the solution flow pattern in the helix cell used, it can be concluded that the entrance effects do not affect the mass-transfer data. These data do not depend on the length of the electrolytic cell.

\subsection{Current efficiency for copper deposition}

The current efficiency, $\eta_{\mathrm{Cu}}$, for copper deposition during cathodic polarization of a round bar were determined as described in [1]. Experiments were carried out with solutions containing various concentrations of $\mathrm{CuSO}_{4}$ and $\mathrm{H}_{2} \mathrm{SO}_{4}$ and at current

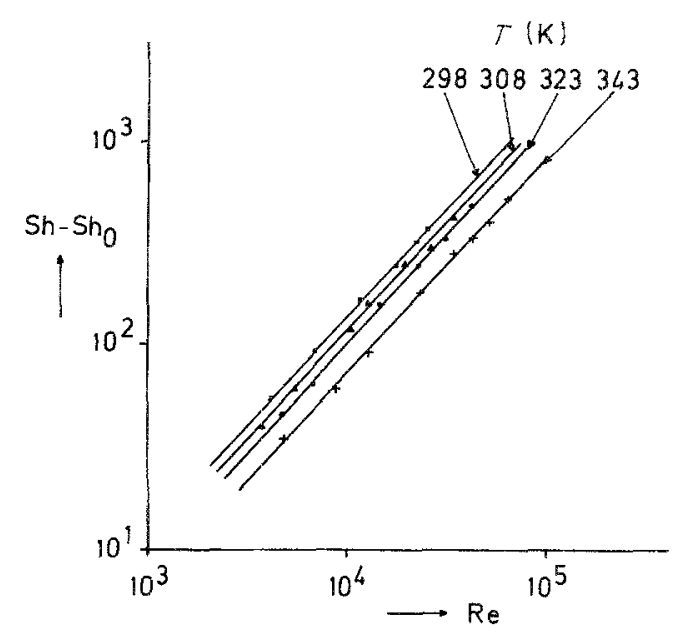

Fig. 8. The difference $\mathrm{Sh}-\mathrm{Sh}_{0}$ plotted against $\mathrm{Re}$ on a double logarithmic scale for a working cylindrical platinum electrode. Conditions as for Fig. 4.

densities from $5-20 \mathrm{kA} \mathrm{m}^{-2}$, solution flow rates, $v_{c}$, from 0.07 to $0.50 \mathrm{~m} \mathrm{~s}^{-1}$ and at temperatures from $303-343 \mathrm{~K}$. The helix cell used for current efficiency measurements had a central tube with an inner diameter of $15 \mathrm{~mm}$ and two spiralled slots with a $4.3 \mathrm{~mm}$ width in the central tube.

To minimize the resistivity of the $\mathrm{CuSO}_{4}-\mathrm{H}_{2} \mathrm{SO}_{4}$ solution, the concentration of $\mathrm{H}_{2} \mathrm{SO}_{4}$ was maximal at a fixed $\mathrm{CuSO}_{4}$ concentration for a temperature of $288 \mathrm{~K}$. The composition numbers of the $\mathrm{CuSO}_{4}$ $\mathrm{H}_{2} \mathrm{SO}_{4}$ solution used were $15.0 / 2.0,12.5 / 5.0,10.7 / 10.0$ and $9.3 / 15.0$, where the first number of the combination indicates the weight per cent of $\mathrm{CuSO}_{4}$ and the second the weight per cent of $\mathrm{H}_{2} \mathrm{SO}_{4}$.

Figure 9 shows $\eta_{\mathrm{Cu}}$ as a function of current density for solutions of various compositions and at a solution flow rate $v_{\mathrm{c}}=0.37 \mathrm{~m} \mathrm{~s}^{-1}$ and $T=323 \mathrm{~K}$. The visually observed formation of dendrites occurs in the region below the dotted line of Fig. 9. This line is only a rough indication for the boundary of formation of copper dendrites. This region is also indicated in Figs 10 and 11. Figure 10 shows the effect of the flow rate of solution, $v_{c}$, for the $12.5 / 5$ solution at various current densities and $323 \mathrm{~K}$.

The effect of temperature is shown in Fig, 11 for solutions of various compositions and at $10 \mathrm{kA} \mathrm{m}^{-2}$

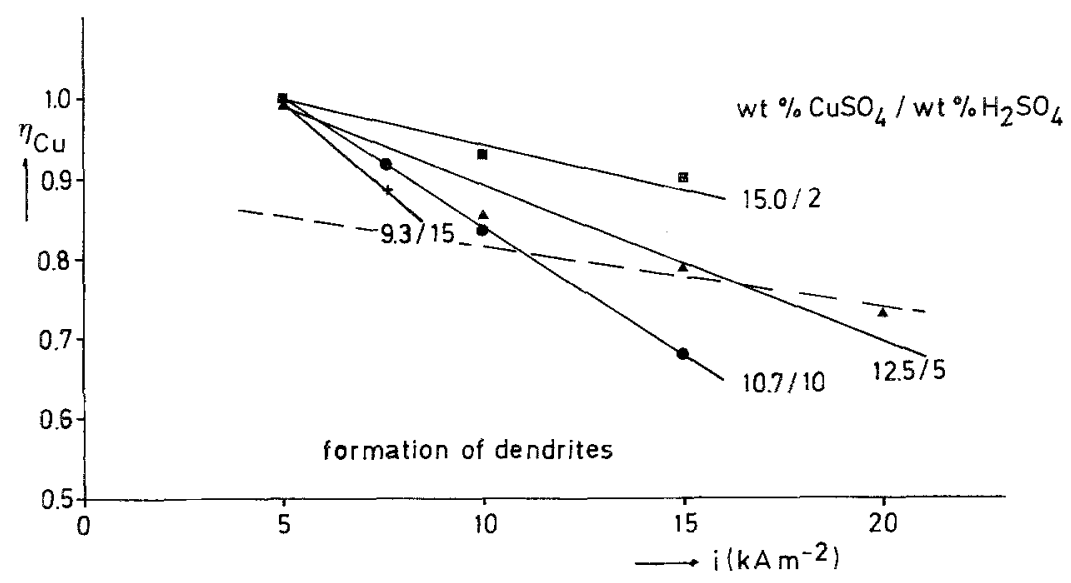

Fig. 9. Copper current efficiency as a function of current density during copper deposition on a round bar at a solution flow rate of $0.37 \mathrm{~m} \mathrm{~s}^{-1}$ and a temperature of $323 \mathrm{~K}$ and in various compositions of the $\mathrm{CuSO}_{4}-\mathrm{H}_{2} \mathrm{SO}_{4}$ bath. 


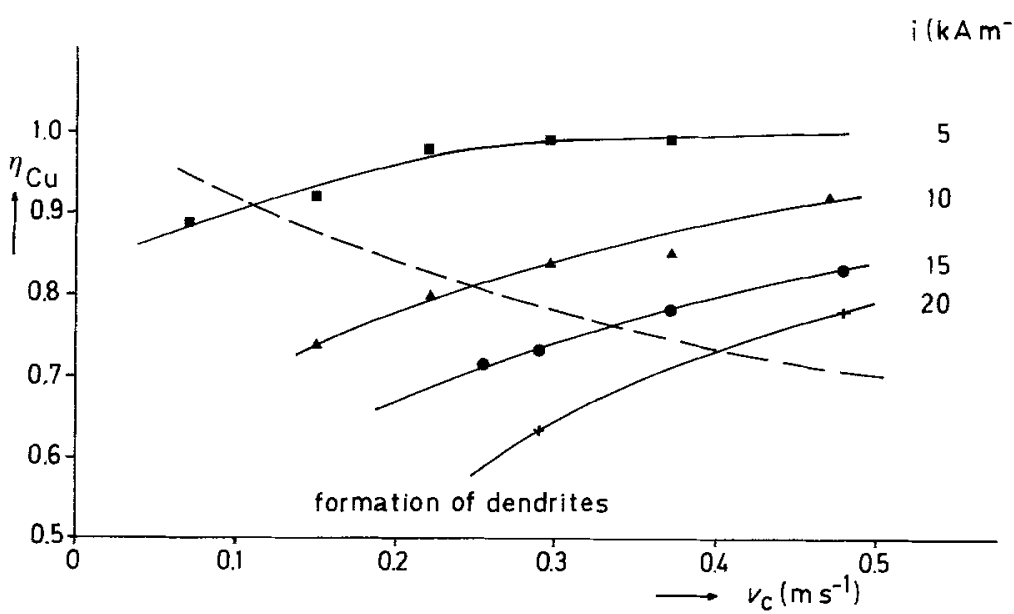

Fig. 10. Copper current efficiency as a function of flow rate of solution during copper deposition on a round bar in a solution containing 12.5 weight per cent $\mathrm{CuSO}_{4}$ and 5.0 weight per cent $\mathrm{H}_{2} \mathrm{SO}_{4}$ at various current densities and at $323 \mathrm{~K}$. and $v_{\mathrm{c}}=0.37 \mathrm{~m} \mathrm{~s}^{-1}$. From Figs $9-11$ it follows that the current efficiency for copper deposition increases with increasing $\mathrm{CuSO}_{4}$ concentration, temperature and flow rate of solution and with decreasing current density.

From the experimental results, a correlation for the current efficiency for copper deposition on a round bar $9 \mathrm{~mm}$ in outer diameter in a helix cell with $15 \mathrm{~mm}$ in inner diameter and $4.3 \mathrm{~mm}$ in width of slot has been deduced. This correlation is given by

$$
\begin{aligned}
\frac{\eta_{\mathrm{Cu}}}{1-\eta_{\mathrm{Cu}}}= & 10.6\left[i^{-1.6}\right] 10^{0.57 v_{\mathrm{c}}}+9.8 X_{1}-2.0 \times 10^{3} \\
& \times\left(\frac{1}{T}-\frac{1}{323}\right)
\end{aligned}
$$

where $i$ is in $\mathrm{kA} \mathrm{m}^{-2} ; v_{\mathrm{c}}$ in $\mathrm{m} \mathrm{s}^{-1} ; T$ in $\mathrm{K} ; X_{1}$ weight per cent $\mathrm{CuSO}_{4}$ in $\mathrm{CuSO}_{4} / \mathrm{H}_{2} \mathrm{SO}_{4}$ solution.

Similar results have been obtained with another type of cell [1] where the solution flow was also directed normal to the axis of a round bar. The main difference between the types of cell is the shape of the slots in the central cylinder, viz., helical slots in the helix cell and rectangular slots in the other.

From the results on mass transfer to a round bar in a helix cell with central cylinders of various inner diameters and with central cylinders having slots differing in width, it follows that the current efficiency for copper deposition increases with decreasing gap width between the round bar and the central cylinder and with decreasing width of slots in the central cylinder. From the current efficiency and mass-transfer experi- ments it follows that very high rates of copper deposition, e.g. higher than $10 \mathrm{kAm}^{-2}$, for the $\mathrm{CuSO}_{4}-$ $\mathrm{H}_{2} \mathrm{SO}_{4}$ baths used in practice can be achieved with helix cells where the solution flow is directed to the axis of a round bar. Because of the configuration of the helix cell, a round bar can be covered with a copper layer of uniform thickness when the bar is transported through the helix cell.

\section{References}

[1] L. J. J. Janssen, J. Appl. Electrochem. 18 (1988) 339

[2] G. Agde and H. Barkholt, Z. Angew. Chem. 40 (1927) 374

[3] A. J. Arvia, J. C. Barim and J. S. W. Carroza, Electrochim. Acta 11 (1966) 881

[4] T. I. Quickenden and X. Jiang, Electrochim. Acta 29 (1984) 693.

[5] G. W. Tindall and S. Bruckenstein, Anal. Chem. 40 (1968) 1051.

[6] R. N. O'Brien and C. Rosenfield, J. Phys. Chem. 67 (1963) 643

[7] J. G. Knudsen and D. L. Katz, 'Fluid Dynamics and Heat Transfer', McGraw-Hill Book Co., New York (1958) pp. 81-82.

[8] E. W. Washburn, 'International Critical Tables', Vol. V, 12. McGraw-Hill Book Company, New York and London, 1929 .

[9] Landolt Bornstein, 'Zahlenwerte und Funktionen aus Physik, Chemie, Astronomie, Geophysik and Technik', Springer Verlag, Berlin, II. Band, 5. Teil, Bandteil a (1969) 631

[10] D. J. Pickett, 'Electrochemical Reactor Design', 2nd edn, Elsevier Scientific Publishing Company, Amsterdam (1977).

11] P. Grassmann, N. Ibl and J. Trüb, Chem. Ing. Tech. 33 (1961) 529

[12] A. Tvarusko, J. Electrochem. Soc. 120 (1973) 87.

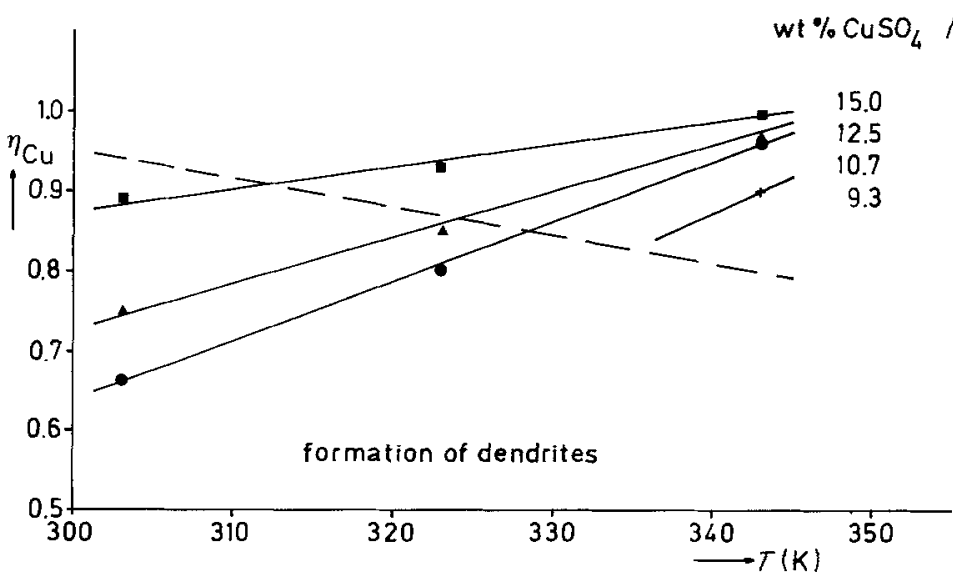

Fig. 11. Copper current efficiency as a function of temperature during copper deposition on a round bar in a solution containing various concentrations of $\mathrm{H}_{2} \mathrm{SO}_{4}$ and $\mathrm{CuSO}_{4}$, at a current density of $10 \mathrm{kA} \mathrm{m}^{-2}$ and a solution flow rate of $0.37 \mathrm{~m} \mathrm{~s}^{-1}$. 